\title{
Detecting tumor-infiltrating Forkhead box P3-positive T cells in the prognosis of lung adenocarcinoma: Possible role of clustering tumor interleukin-12 subunit alpha and transforming growth factor beta 1 expression
}

\author{
Hiroyasu Matsuoka ${ }^{1, A-F}$, Hirochika Matsubara ${ }^{1, D-F}$, Aya Sugimura ${ }^{1, C, F}$, Tsuyoshi Uchida ${ }^{1, C, F}$, Tamo Kunimitsu ${ }^{1, C, F}$, \\ Tomofumi Ichihara ${ }^{1, C, F}$, Yuichiro Oonuki ${ }^{2, C, F}$, Yoshihiro Miyauchi ${ }^{2, C, F}$, Tetsuo Kondo ${ }^{3, A, C}$, Hiroyuki Nakajima ${ }^{1, A, C, F}$ \\ ${ }^{1}$ Department of Surgery, Faculty of Medicine, University of Yamanashi, Chuo, Japan \\ 2 Department of Thoracic Surgery, National Hospital Organization Disaster Medical Center, Tachikawa, Tokyo, Japan \\ ${ }^{3}$ Department of Pathology, Faculty of Medicine, University of Yamanashi, Chuo, Japan \\ A - research concept and design; $\mathrm{B}$ - collection and/or assembly of data; $\mathrm{C}$ - data analysis and interpretation; \\ $D$ - writing the article; $E$ - critical revision of the article; $F$ - final approval of the article
}

\section{Address for correspondence}

Hiroyasu Matsuoka

E-mail: aphyosemion@hotmail.co.jp

Funding sources

None declared

Conflict of interest

None declared

\section{Acknowledgements}

We would like to thank Professor Atsuhito Nakao and Dr. Hirok Ishii for their valuable advice regarding the assessment of Tregs. We would like to thank Ms. Wakaba Iha, Dr. Kazuyoshi Hirayama and Dr. Shota Tanaka for their advice regarding experimental technique. We would like to thank Editage (www.editage.jp) for editorial support in the form of medical writing.

Received on February 25, 2019

Reviewed on September 6, 2019

Accepted on May 1,2020

Published online on June 30, 2020

Cite as

Matsuoka H, Matsubara H, Sugimura A, et al. Detecting tumor-infiltrating Forkhead box P3-positive T cells in the prognosis of lung adenocarcinoma: Possible role of clustering tumor interleukin-12 subunit alpha and transforming growth factor beta 1 expression. Adv Clin Exp Med. 2020;29(6):715-725. doi:10.17219/acem/121922

DOI

10.17219/acem/121922

Copyright

Copyright by Author(s)

This is an article distributed under the terms of the

Creative Commons Attribution 3.0 Unported (CC BY 3.0)

(https://creativecommons.org/licenses/by/3.0/)

\begin{abstract}
Background. While regulatory $T$ cells (Tregs) are a poor prognostic factor for lung cancer, they may be detected as Forkhead box P3+ (FOXP3+) and cluster of differentiation (-CD) 4+ T cells by classifying FOXP3+CD4+ T cells into different subpopulations of CD4 cells.
\end{abstract}

Objectives. To classify clusters of tumor-infiltrating Tregs in lung adenocarcinoma based on the mRNA expression levels of interleukin-12 subunit alpha (IL2A) and transforming growth factor beta 1 (TGFBT) in tumor specimens.

Material and methods. Seventy-nine patients with lung adenocarcinoma were evaluated in this study. Clinical data were obtained from the patients' medical records, while tumor tissue samples were preserved as formalin-fixed paraffin-embedded (FFPE) tissue specimens. Immunohistochemical staining for CD4, CD8 and FOXP3 was performed and stained cell counts were obtained under 5 high-power fields. CDNA was synthesized from total RNA extracted from FFPE tissue specimens and amplified with Taqman probes for FOXP3, IL12A, TGFBI, and the glyceraldehyde-3-phosphate dehydrogenase gene.

Results. Two clusters were identified: L12AlowTGFB1low (Cluster 1: $n=44$ ) and IL12AhighTGFBThigh (Cluster $2: n=39$ ). Although no significant difference in the FOXP3 + cell/CD4+ cell ratio was observed between the 2 clusters ( $p=0.921$ ), the high FOXP3+/CD4+ cell ratio group showed a significantly poorer relapse-free survival rate than the low FOXP3+/CD4+ cell ratio group in Cluster 1 ( $p=0.031)$.

Conclusions. Although the results revealed no direct association between Tregs and prognosis according to each subtype, these results suggest that if a lung cancer specimen contains low levels of IL12A and TGFBI, the FOXP3+/CD4+ cell ratio is useful for predicting the prognosis of lung cancer.

Key words: adenocarcinoma, prognosis, T-lymphocytes, regulatory 


\section{Introduction}

Tumor-infiltrating Forkhead box P3+ (FOXP3+) and regulatory $\mathrm{T}$ cells (Tregs) are poor prognostic factors for many types of malignant tumors, ${ }^{1}$ including lung cancer. $^{2-8}$ Recently, FOXP3+ and cluster of differentiation (CD) 4+ T cells in peripheral blood lymphocytes were classified into 3 subpopulations based on the expression levels of FOXP3 and CD45RA: subpopulation I, FOX$P 3^{\text {low }} C D 45 R A+$; subpopulation II, FOXP $3^{\text {high }} C D 45 R A-$; and subpopulation III, FOXP ${ }^{\text {low }} C D 45 R A-$. Subpopulation II, known as effector Tregs, exhibits suppressive activity and increased numbers of these cells are found among tumor-infiltrating lymphocytes compared to peripheral blood lymphocytes. ${ }^{9,10}$ In colorectal cancer (CRC), tumor infiltration, predominantly by FOXP3 $3^{\text {high }} / \mathrm{CD} 4+$ Tregs, is strongly associated with the prognosis of malignant tumors. ${ }^{11}$ In biomedical laboratories, flow cytometry is used to identify Tregs due to the difficulty in assessing effector Tregs using only formalin-fixed, paraffin-embedded (FFPE) tissues.

Saito et al. described a classification system based on mRNA expression of interleukin-12 subunit alpha (IL12A) and transforming growth factor beta 1 (TGFB1) in CRC specimens to distinguish subpopulations of (nonTreg) poor cases from Fr-III rich cases. ${ }^{11}$ They classified CRC into 2 groups using this method and performed a survival analysis based on the FOXP3 mRNA expression level in the same specimens. The current study used the same approach to evaluate lung adenocarcinoma (LAC) using only FFPE tissue. As tumor cells frequently express FOXP3 in lung cancer, this method revealed FOXP3 mRNA expression in lung cancer specimens, as well as the number of tumor-infiltrating Tregs. ${ }^{3,7,12-14}$ In flow cytometry, Tregs are assessed as a fraction using the ratio of each Fr Treg/ CD4+ mononuclear cell count. ${ }^{11}$ Thus, the FOXP3+/CD4+ ratio in FFPE tissue specimens was also assessed using immunohistochemical analysis.

Lund adenocarcinoma contains several histological subpopulations that include lepidic, acinar, papillary, solid, mucinous, and micropapillary subpopulations. ${ }^{15}$ Cell density of lepidic LAC is lower than that of other subpopulations. Consequently, the stained cell counts of lepidic subpopulations tend to be lower than that of other subpopulations. Adenocarcinomas in situ and minimally invasive adenocarcinomas have been associated with positive prognoses, ${ }^{16}$ which may be partly due to the generally lower numbers of FOXP3+ cells and tumor cells in these subpopulations, compared with others. However, this feature alone does not enable adequate assessment of the relationship between cell counts and prognosis. Furthermore, FOXP3 may appear in lung tumor cells, suggesting that the number of tumor-infiltrating Tregs is not adequately reflected by FOXP3 levels in tumor tissue.

Against such a background, the objective of this study was to classify clusters of tumor-infiltrating Tregs in LAC based on the mRNA expression levels of $I L 12 \mathrm{~A}$ and TGFB1. This study was conducted to determine whether the FOXP3+/CD4+ cell ratio is a better estimator of the number of tumor-infiltrating Tregs in a tissue sample, and whether FOXP3+-rich regions are better for evaluating stained cell counts without being affected by the biased association with histological subpopulations.

\section{Material and methods}

\section{Patients and samples}

Seventy-nine patients with LAC who underwent pulmonary resection and regional lymph node dissection at University of Yamanashi hospital. between 2004 and 2011 were included in this study. Patients were excluded if they had other malignancies 5 years before or 2 years after LAC, complications related to autoimmune disease, had undergone treatment with non-radical excision, or had been treated using adjuvant chemotherapy. Clinical and pathological data was obtained from the patients' medical records at the hospital. Pathological data were re-evaluated according to the $8^{\text {th }}$ edition of the Tumor-Node-Metastasis Classification for lung cancer. ${ }^{17}$

\section{Ethical considerations}

Tumor tissue samples were obtained during pulmonary resection and preserved as FFPE tissue specimens. All participants provided informed written consent prior to pulmonary resection. The study was approved by the Ethics Committee of University of Yamanashi. The research was conducted in accordance with the 2013 Declaration of Helsinki.

\section{Immunohistochemical staining}

The FFPE tissue blocks were sliced into $3 \mu \mathrm{m}$-thick tissue sections using a sliding microtome (Yamato Kohki Industrial Co., Ltd., Asaka, Japan). Following deparaffinization in xylene and dehydration using increasing concentrations of alcohol, sections were pretreated by heat-mediated antigen retrieval in a $95^{\circ} \mathrm{C}$ water bath with Target Retrieval Solution (DAKO, Glostrup, Denmark) at pH 6.0 for 30 min (CD4), pH 9.0 for $30 \mathrm{~min}$ (CD8) and $\mathrm{pH} 9.0$ for $40 \mathrm{~min}$ (FOXP3). Prior to the application of CD8 and FOXP3 antibodies, endogenous peroxidase activity was inhibited by incubating the samples in 3.0\% hydrogen peroxidase for $15 \mathrm{~min}$ at $37^{\circ} \mathrm{C}$. For CD4, endogenous peroxidase activity was inhibited following primary antibody incubation using the same method. After protein blocking with Blocking I (Nacalai Tesque, Kyoto, Japan) for $15 \mathrm{~min}$ at $37^{\circ} \mathrm{C}$, sections were incubated for an additional $2 \mathrm{~h}$ at $37^{\circ} \mathrm{C}$ with anti-CD4 (rabbit monoclonal, dilution 1:100; ab133616), anti-CD8 (mouse monoclonal, dilution 1:50; ab17147) and 
anti-FOXP3 (mouse monoclonal, dilution 1:100; ab20034) antibodies (Abcam, Cambridge, UK). After being washed 3 times with phosphate-buffered saline (PBS), sections were incubated for $30 \mathrm{~min}$ at $37^{\circ} \mathrm{C}$ with secondary antibodies: Histofine Max-PO(M) (horseradish peroxidase (HRP)conjugated anti-mouse immunoglobulin polyclonal) and Histofine Max-PO(R) (HRP-conjugated anti-rabbit immunoglobulin polyclonal; Nichirei Biosciences, Inc., Tokyo, Japan). A 3,3'-diaminobenzidine peroxidase stain kit (Nacalai Tesque) was used as the chromogen. Sections were counterstained using hematoxylin. Positive and negative staining controls for CD4/8 and FOXP3 were prepared using lymph node and tonsil sections, respectively. Staining of the positive control was performed as described above. The negative control was stained using PBS rather than with primary antibodies.

\section{Evaluation of immunohistochemical staining}

For CD4 and FOXP3, continuous sections were stained and counted. FOXP3+-rich regions in the tumor stroma were selected for counting CD4+ and FOXP3+ cell numbers. CD8+-rich regions in the tumor stroma were selected for counting CD8+ cell numbers. Each count was based on 5 fields from high-powered digital images $(\times 400$ magnification). The average cell count was used for statistical analysis. FOXP3+ tumors were defined as $>20 \%$ staining of tumor cells in a section as previously described. ${ }^{3}$

\section{Quantitative real-time polymerase chain reaction}

Total RNA was extracted from FFPE tumor specimens using an Ambion ${ }^{\mathrm{TM}}$ MagMAX $^{\mathrm{TM}}$ FFPE Total Nucleic Acid Isolation Kit (Invitrogen, Carlsbad, USA). Next, cDNA was synthesized from $0.5 \mu \mathrm{g}$ of total RNA using a SuperScript III Reverse Transcriptase Kit with random primers (Invitrogen) and amplified via $10.0 \mu \mathrm{M}$ each of Taqman probe (FOXP3, IL12A, TGFB1, and glyceraldehyde-3-phosphate dehydrogenase (GAPDH); Applied Biosystems, Foster City, USA) and $10.0 \mu \mathrm{L}$ of Taqman Gene Expression Master Mix (Life Technologies, Carlsbad, USA) according to the manufacturer's instructions. Relative mRNA expression was evaluated after normalization to GAPDH expression.

\section{Tumor cell content analysis}

Tissue sections continuous to FFPE tumor specimens used to extract RNA were stained with hematoxylin and eosin (H\&E) and analyzed using ImageJ software (National Institutes of Health, Bethesda, USA; http://rsb.info.nih. gov/ij/). Analysis was based on 5 fields of view randomly chosen within the limits of RNA extraction in high-powered digital images ( $\times 400$ magnification). The margins of the tumor cells were marked and the enclosed area was calculated as the area of the tumor cells. Total cell area was calculated by excluding any cell-free areas from the overall area of each image. The tumor content ratio was determined by the tumor cell area divided by the total cell area.

\section{Statistical analyses}

Categorical variables were compared using Fisher's exact tests and continuous variables were compared using non-parametric Mann-Whitney U tests or Kruskal-Wallis one-way analysis of variance (ANOVA) and post hoc Tukey's tests. All statistical analyses were conducted using SPSS v. 24.0 software (IBM Corp., Armonk, USA). Statistical significance was set at $\mathrm{p}<0.05$. The cut-off value for experimental data was defined using Youden's index (J) as follows; $\mathrm{J}$ = sensitivity + specificity -1 , for variables with $\mathrm{p}<0.05$ (recurrence: "yes" vs "no"). Remaining continuous variables were divided by the median value. Survival curves were estimated using the Kaplan-Meier method and compared using the log-rank test. Cox proportional hazards models were used for univariate and multivariate analyses. Relapse-free survival was used as a dependent variable. Independent variables were selected from categorical variables that were significant according to univariate analysis $(\mathrm{p}<0.05)$.

\section{Results}

\section{Patient characteristics}

A total of 79 LAC patients were included in this study. The mean age was 67.2 years (range: $32-88$ years) and $38.0 \%(30 / 79)$ were males. Nineteen percent $(15 / 79)$ of these patients were relapsed LAC cases. The mean total tumor size was $2.48 \mathrm{~cm}$ (range: $0.6-8.0 \mathrm{~cm}$ ), and $81 \%(64 / 79)$ of patients were at the pathological stage of $0-1$. Histological subtypes of the tumors were lepidic in 30/79 cases, acinar in $17 / 79$, papillary in $16 / 79$, solid in $9 / 79$, and mucinous in $7 / 79$. Fifty-four percent (43/79) of tumor samples were positive for FOXP3 staining.

\section{Immunohistochemical staining analysis}

In the positive controls, the cytoplasm of lymphocytes in lymph node tissue specimens was stained with CD4 and CD8 antibodies, whereas nuclei were stained with FOXP3 antibodies. For positive controls, cells displaying nuclear FOXP3 staining were confirmed as lymphocytes using CD4/CD8 antibodies, while cells displaying cytoplasmic FOXP3 staining were confirmed as non-lymphocytes. In negative controls, it was confirmed that tonsil tissue specimens were not stained by secondary antibodies in the absence of primary antibodies. 

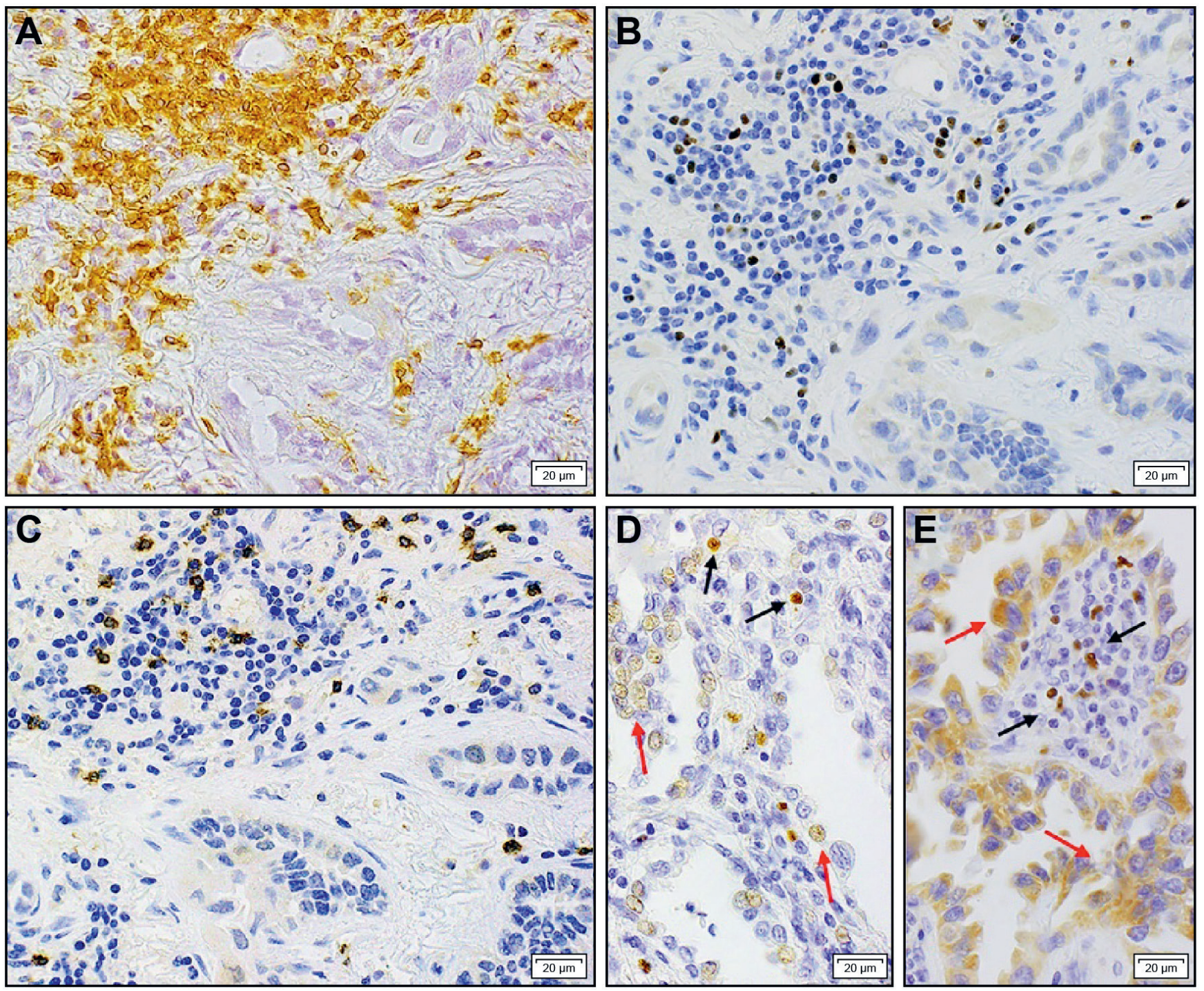

Fig. 1. Forkhead box P3 (FOXP3) antibody staining of lung cancer tissues. A. Staining of lymphocyte cytoplasm for CD4. B. Staining of nuclei for FOXP3. C. Staining of cytoplasm for CD8. D. FOXP3 staining was observed in nuclei of tumor cells (red arrow) and nuclei of lymphocytes (black arrow). E. FOXP3 staining was observed in the cytoplasm of tumor cells (red arrow) and nuclei of lymphocytes (black arrow). The red arrows indicate stained cancer nuclei (D) and cytoplasm (E). The black arrows indicate stained lymphocytes. All images were acquired using tumor tissues

Forty-three LAC samples (54.4\%) were positively stained with FOXP3 antibodies (Fig. 1A-E). In these samples, FOXP3 was mainly concentrated in areas rich in CD4+ and/or CD8+ cells and was localized to the nuclei of lymphocytes, as well as to either the nuclei or cytoplasm of non-lymphocytic tumor cells (Fig. 1D,E). The mean FOXP3+ cell count in tumor samples from relapsed patients $(\mathrm{n}=15)$ was significantly higher than that in samples from non-relapsed patients $(n=64)$ at 63 cells compared to 37 cells, respectively $(\mathrm{p}=0.018)$. There were more $\mathrm{CD} 4+$ cells than FOXP3+ cells in all LAC samples, and therefore FOXP3+/CD4+ cell count ratios ranged between 0.05 and 0.48 . The mean FOXP3+/CD4+ cell count ratio was significantly higher in relapsed than in non-relapsed patients ( 0.23 vs 0.16 , respectively; $\mathrm{p}=0.012)$ FOXP3+/CD $8+$ cell count ratios varied between samples, within a range between 0.04 and 1.94 .

\section{mRNA expression and clustering analysis}

The median relative mRNA expression levels of FOXP3, IL12A and TGFB1 in lung tumor specimens were set to 1.0. The mRNA expression level ranges were $0.10-5.12,0.07-$ 5.58 and $0.14-3.36$, respectively. Two clusters were identified by unsupervised hierarchical clustering analysis based on IL12A and TGFB1 expression levels. A heatmap was generated, where red indicated high levels of mRNA expression and blue indicated low levels of mRNA expression for each gene of interest. Most Cluster 1 analyses exhibited low levels of IL12A and TGFB1 expression, while Cluster 2 analyses exhibited high mRNA expression levels of IL12A and TGFB1 (Fig. 2).

Although lung tumor FOXP3 expression was significantly higher in Cluster 2 than in Cluster $1(\mathrm{p}<0.001)$, for FOXP3+ cases compared with FOXP3- cases $(\mathrm{p}<0.05)$ 


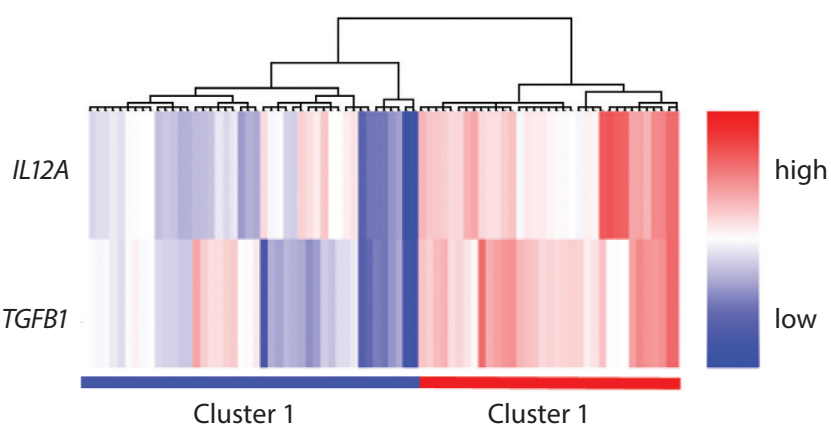

Fig. 2. Expression levels of interleukin-12 subunit alpha (IL12A) and transforming growth factor beta 1 (TGFB1) in Cluster 2. Heatmap images were created using RNA expression to GAPDH expression ratios (mean value of 3 samples was used in the analysis). Logarithmic transformation was used to determine the normal distributions of RR values, which were standardized using Z-scores. "0" is shown in white and $\pm 2 S D$ is shown in red and blue, respectively

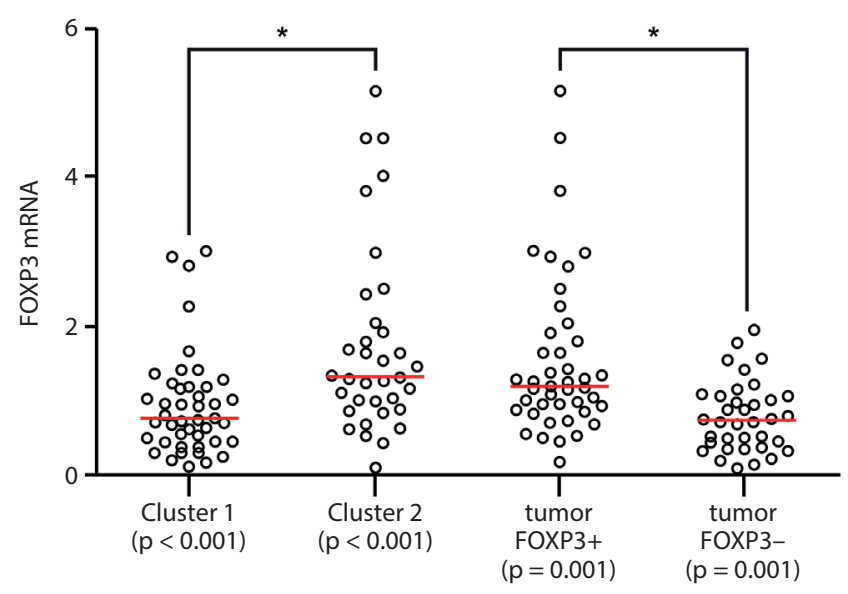

Fig. 3. FOXP3 expression levels in clusters, FOXP3+, and FOXP3-cases.

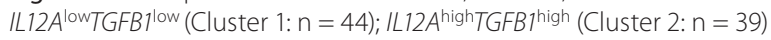

FOXP3 - Forkhead box P3.
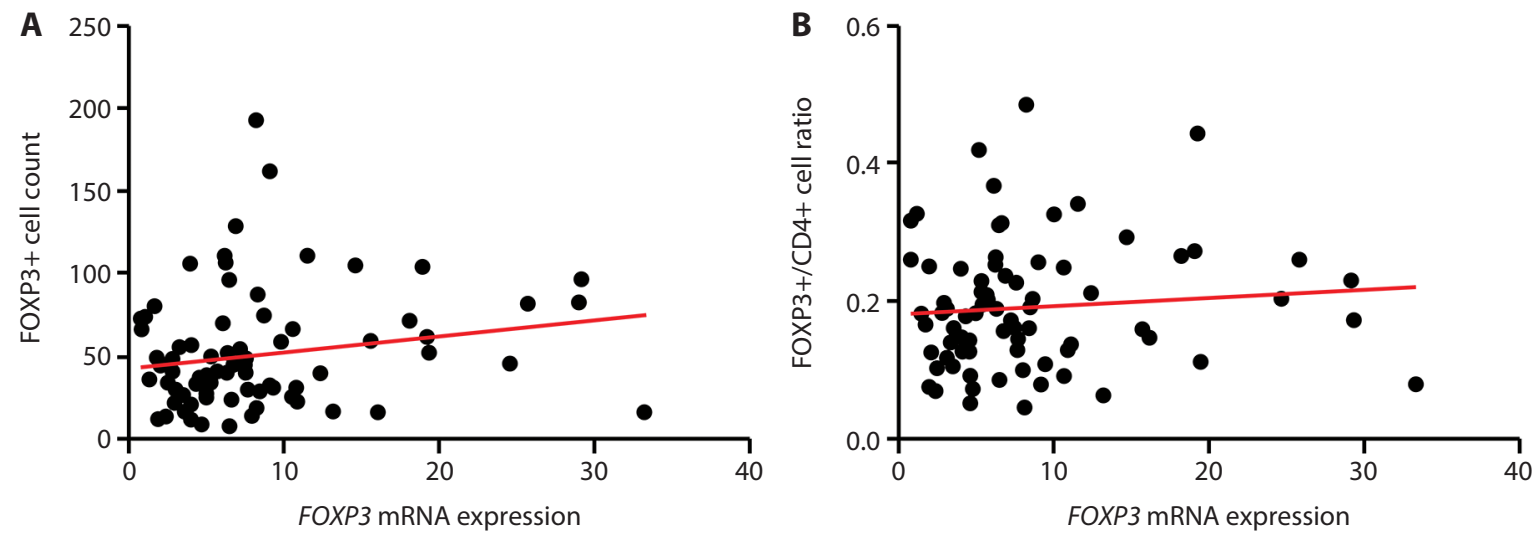

Fig. 4. Correlation analysis for FOXP3 mRNA expression. Correlation between FOXP3 mRNA expression and FOXP3+ cell counts (A) or FOXP3+/CD4+ cell ratio (B) in lung tumor tissues was not significant

(Fig. 3), Spearman's rank-order correlation indicated that FOXP3 mRNA expression was unrelated to FOXP3+ cell counts (correlation coefficients: 0.171, $\mathrm{p}=0.131$; Fig. 4A) or the FOXP3+/CD4+ cell ratio (correlation coefficients: 0.0819, $\mathrm{p}=0.472$; Fig. 4B). Survival curves for all groups are shown (Fig. 5). Cluster 1 showed a higher survival rate compared to Cluster 2, when clusters of all cases were compared.

\section{Association between clinicopathological characteristics and experimental data}

The FOXP3+ cell counts and FOXP3+/CD4+ cell ratios were significantly higher in lung tumor samples from relapsed cases than from non-relapsed cases $(\mathrm{p}=0.018$ and $\mathrm{p}=0.012$, respectively), and expression level of each mRNA was significantly lower in the relapsed groups than in the non-relapsed group ( $\mathrm{p}<0.01)$ (Table 1).

Clusters 1 and 2 comprised 44 and 35 patients, respectively. Cluster 1 patients showed unfavorable pathological characteristics, such as large tumor diameter, lymph node metastasis and vascular invasion, compared with
Cluster 2 patients. Although Cluster 1 patients showed a significantly higher risk of recurrence than Cluster 2 patients $(\mathrm{p}=0.039)$, no significant differences in FOXP3+ cell counts or FOXP3+/CD4+ cell ratios were observed between the 2 clusters. Cluster 1 comprised 14 relapsed patients and 30 non-relapsed patients. FOXP3+ cell counts and FOXP3+/CD4+ and FOXP3+/CD8+ cell ratios were significantly higher in lung tumor samples from relapsed cases than in those from non-relapsed cases of Cluster 1. FOXP3 mRNA expression was significantly lower in samples from relapsed cases than in non-relapsed cases (Table 2).

\section{Association between the tumor cell content and other experimental data}

The mean tumor content ratio was 0.373 (range: $0.088-$ 79.4). When samples were divided into 3 evenly sized groups according to tumor cell content ratio, no significant differences in cell counts or mRNA expression levels were observed. However, the amount of mRNA extracted from the low tumor content ratio group was significantly less than in the high tumor content ratio group (Table 3). 

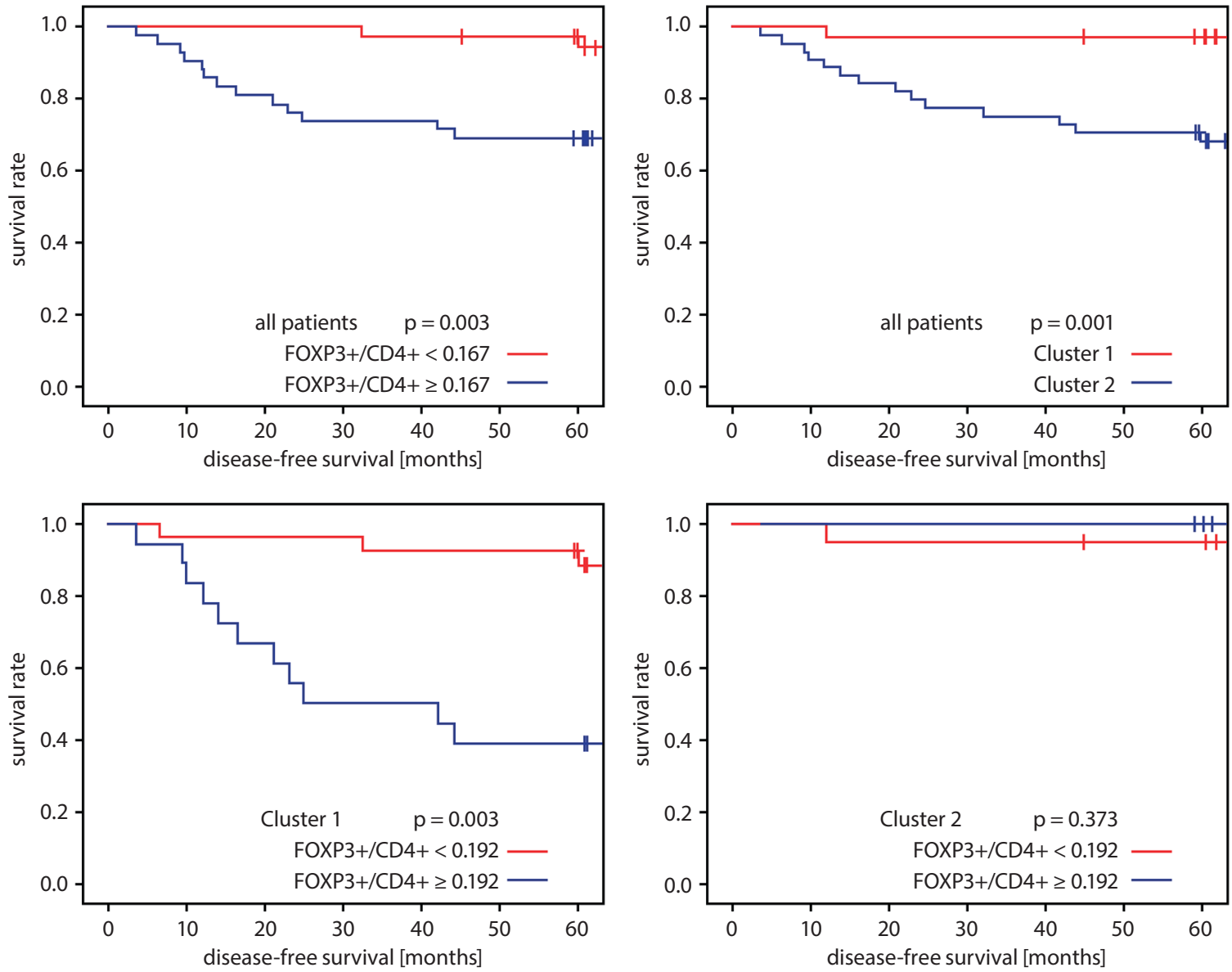

Fig. 5. Survival curves for all groups. The upper left panel shows the FOXP3+/CD4+ ratio of lung tumor tissue samples for all cases. The upper right panel shows the comparison between clusters of all cases. The bottom left panel shows the FOXP3+/CD4+ ratio of Cluster 1 . The bottom right panel shows the comparison of FOXP3+/CD4+ ratio of Cluster 2

FOXP3 - Forkhead box P3; CD - cluster of differentiation. Survival curves were estimated using the Kaplan-Meier method and compared using the log-rank test.

\section{Univariate and multivariate analysis of risk factors affecting relapse-free survival rate}

Univariate analysis of all cases revealed older age ( $>73$ years), larger total tumor size $(>2.9 \mathrm{~cm})$, larger invasion size $(>2.4 \mathrm{~cm})$, advanced $\mathrm{T} / \mathrm{N}$ factor, advanced pathological stage, pleural invasion, advanced tumor grade, lymphatic invasion, vessel invasion, solid adenocarcinoma, higher tumor FOXP3+/CD4+ cell ratio, FOXP3- tumor, lower tumor FOXP3, as well as $I L 12 A$, and TGFB1 mRNA expression levels and larger tumor cell content ratio $(>0.55)$ as poor prognostic factors for relapse-free survival. In Cluster 1 patients, univariate analysis revealed that larger total tumor size $(>3.5 \mathrm{~cm})$, larger invasion size $(>2.4 \mathrm{~cm})$, advanced $\mathrm{N}$ factor, advanced pathological stage, lymphatic invasion, vessel invasion, higher tumor FOXP3+/CD4 cell ratio (>0.192), higher tumor FOXP3+/CD8+ cell ratio $(>0.400)$, as well as lower tumor FOXP3 and TGFB1 mRNA expression levels were poor prognostic factors affecting relapsefree survival (Table 4).
In multivariate analysis of all cases, advanced $\mathrm{N}$ factor, advanced pathological stage, and vessel invasion, were confirmed as independent prognostic factors for relapse-free survival. In Cluster 1 patients, multivariate analysis confirmed larger total tumor size $(>3.5 \mathrm{~cm})$, advanced $\mathrm{N}$ factor, vessel invasion, and higher tumor $F O X P 3+/ C D 4+$ cell ratio $(>0.192)$ as independent prognostic factors for relapse-free survival (Table 5).

\section{Discussion}

Tregs play a key immunosuppressive role in malignant tumors. ${ }^{18-20}$ High tumor-infiltrating Tregs and peripheral blood Treg counts are poor prognostic factors for lung cancer. $^{2-8}$ Treg fractions have been described previously. Flow cytometry is required to distinguish between fractions. In CRC, Saito et al. reported that FOXP3+ non-Tregs in tumor samples were associated with inflammation and that their development depended on the secretion of IL12A and TGFB1 from tumor cells or tumor-associated cells. ${ }^{11}$ 
Table 1. Comparison of FOXP3, ILI2A and TGFB1 mRNA expression levels and patient characteristics

\begin{tabular}{|c|c|c|c|c|c|c|}
\hline \multirow{2}{*}{ Characteristics } & \multicolumn{6}{|c|}{ Mean relative mRNA a expression level (range) } \\
\hline & FOXP3 & $p$-value ${ }^{b}$ & IL12A & $\mathrm{p}$-value ${ }^{\mathrm{b}}$ & TGFB1 & $p$-value ${ }^{b}$ \\
\hline $\begin{array}{l}\text { Age [years] } \\
\qquad \begin{array}{l}<3(n=29) \\
\geq 73(n=50)\end{array}\end{array}$ & $\begin{array}{l}6.76(0.68,29.14) \\
4.88(0.70,33.18)\end{array}$ & 0.32 & $\begin{array}{l}0.25(0.05,1.15) \\
0.15(0.01,0.88)\end{array}$ & $<0.001$ & $\begin{array}{l}0.89(0.12,2.57) \\
0.53(0.11,2.53)\end{array}$ & 0.04 \\
\hline $\begin{array}{l}\text { Sex } \\
\text { male }(n=30) \\
\text { female }(n=49)\end{array}$ & $\begin{array}{l}4.91(0.68,29.01) \\
7.45(1.06,33.18)\end{array}$ & 0.03 & $\begin{array}{l}0.19(0.02,1.15) \\
0.23(0.01,1.01)\end{array}$ & 0.45 & $\begin{array}{l}0.72(0.11,2.57) \\
0.88(0.11,2.46)\end{array}$ & 0.29 \\
\hline $\begin{array}{c}\text { Emphysema } \\
\text { yes }(n=13) \\
\text { no }(n=66)\end{array}$ & $\begin{array}{l}4.59(2.43,18.90) \\
6.76(0.68,33.18)\end{array}$ & 0.47 & $\begin{array}{l}0.14(0.04,0.42) \\
0.23(0.01,1.15)\end{array}$ & 0.03 & $\begin{array}{l}0.53(0.15,1.16) \\
0.88(0.11,2.57)\end{array}$ & 0.05 \\
\hline $\begin{array}{l}\text { Tumor factor } \\
\text { Tis, } 1(n=57) \\
\text { T2-4 }(n=32)\end{array}$ & $\begin{array}{l}7.12(0.68,33.18) \\
4.16(0.70,18.90)\end{array}$ & 0.03 & $\begin{array}{l}0.24(0.01,1.15) \\
0.13(0.02,0.35)\end{array}$ & 0 & $\begin{array}{l}0.94(0.11,2.57) \\
0.47(0.11,1.41)\end{array}$ & $<0.001$ \\
\hline $\begin{array}{l}\text { Nodal factor } \\
\text { NO }(n=70) \\
\text { N1,2 }(n=9)\end{array}$ & $\begin{array}{c}6.97(0.68,33.18) \\
2.95(1.82,9.82)\end{array}$ & 0.01 & $\begin{array}{l}0.23(0.02,1.15) \\
0.09(0.01,0.22)\end{array}$ & 0 & $\begin{array}{l}0.85(0.11,2.57) \\
0.45(0.11,1.01)\end{array}$ & 0.01 \\
\hline $\begin{array}{l}\text { Pathological stage } \\
\text { stage } 0, \text { I }(n=64) \\
\text { stage II, III }(n=15)\end{array}$ & $\begin{array}{l}6.97(0.68,33.18) \\
3.52(0.70,18.90)\end{array}$ & 0.03 & $\begin{array}{l}0.24(0.01,1.15) \\
0.12(0.02,0.31)\end{array}$ & 0 & $\begin{array}{l}0.92(0.11,2.57) \\
0.45(0.11,1.01)\end{array}$ & 0 \\
\hline $\begin{array}{l}\text { pl factor } \\
\text { pl0 }(n=69) \\
\text { pl1-3 }(n=10)\end{array}$ & $\begin{array}{l}6.83(0.68,33.18) \\
3.12(1.06,14.52)\end{array}$ & 0.01 & $\begin{array}{l}0.23(0.01,1.15) \\
0.15(0.05,0.35)\end{array}$ & 0.13 & $\begin{array}{l}0.87(0.11,2.57) \\
0.45(0.22,1.05)\end{array}$ & 0.02 \\
\hline $\begin{array}{l}\text { Lymphatic invasion } \\
\text { negative }(n=61) \\
\text { positive }(n=18)\end{array}$ & $\begin{array}{l}6.83(0.68,33.18) \\
5.32(0.70,14.52)\end{array}$ & 0.14 & $\begin{array}{l}0.24(0.05,1.15) \\
0.13(0.01,0.31)\end{array}$ & 0 & $\begin{array}{l}0.94(0.12,2.57) \\
0.37(0.11,1.01)\end{array}$ & $<0.001$ \\
\hline $\begin{array}{l}\text { Vessel invasion } \\
\text { negative }(n=62) \\
\text { positive }(n=17)\end{array}$ & $\begin{array}{l}6.76(0.68,33.18) \\
4.46(0.70,15.57)\end{array}$ & 0.1 & $\begin{array}{l}0.24(0.04,1.15) \\
0.13(0.01,0.35)\end{array}$ & 0 & $\begin{array}{l}0.93(0.12,2.57) \\
0.45(0.11,1.21)\end{array}$ & $<0.001$ \\
\hline $\begin{array}{l}\text { Grade } \\
\qquad \begin{array}{l}\text { G1 }(n=37) \\
\text { G2,3 }(n=42)\end{array}\end{array}$ & $\begin{array}{l}7.47(0.68,33.18) \\
5.81(0.70,19.29)\end{array}$ & 0.04 & $\begin{array}{l}0.27(0.07,1.15) \\
0.17(0.01,0.88)\end{array}$ & 0 & $\begin{array}{l}1.05(0.29,2.57) \\
0.50(0.11,2.53)\end{array}$ & $<0.001$ \\
\hline $\begin{array}{l}\text { Histological subtype } \\
\text { lepidic }(n=30) \\
\text { mucinous }(n=7) \\
\text { acinar }(n=17) \\
\text { papillary }(n=16) \\
\text { solid }(n=9)\end{array}$ & $\begin{array}{l}8.17(0.68,33.18) \\
5.28(1.28,10.55) \\
5.61(1.06,19.29) \\
6.54(2.43,15.57) \\
2.95(0.70,9.82)\end{array}$ & 0.01 & $\begin{array}{l}0.28(0.07,1.15) \\
0.18(0.09,1.01) \\
0.20(0.05,0.88) \\
0.18(0.05,0.43) \\
0.08(0.01,0.49)\end{array}$ & 0.01 & $\begin{array}{l}1.11(0.29,2.57) \\
0.76(0.45,1.50) \\
0.69(0.22,2.53) \\
0.52(0.12,1.21) \\
0.33(0.11,1.55)\end{array}$ & $<0.001$ \\
\hline $\begin{array}{l}\text { Tumor FOXP3 staining } \\
\text { negative }(n=36) \\
\text { positive }(n=43)\end{array}$ & $\begin{array}{l}4.38(0.68,29.01) \\
7.67(1.06,33.18)\end{array}$ & 0 & $\begin{array}{l}0.20(0.02,1.15) \\
0.23(0.01,1.01)\end{array}$ & 0.57 & $\begin{array}{l}0.73(0.11,1.96) \\
0.90(0.11,2.57)\end{array}$ & 0.22 \\
\hline
\end{tabular}

FOXP3 - Forkhead box P3; IL12A - interleukin-12 subunit alpha; TGFB1 - transforming growth factor beta 1; G - grade. ${ }^{a}$ mRNA level relative to GAPDH: ${ }^{b}$ mean expression levels for each mRNA type was compared between patient characteristic subgroups. Categorical variables were compared using Fisher's exact tests and continuous variables were compared using nonparametric Mann-Whitney U tests or Kruskal-Wallis one-way ANOVA and post hoc Tukey tests.

Particularly, TGFB1 influences metastasis through epithelial-to-mesenchymal transition by transactivating epidermal growth factor signaling. ${ }^{21}$

Cluster analysis performed as previously described ${ }^{11}$ revealed 2 clusters of tumor samples. Cluster 1 was characterized by $I L 12 A^{\text {low } T G F B 1^{\text {low }}}$ and Cluster 2 by $I L 12 A^{\text {high }} T$ GFB1 ${ }^{\text {high }}{ }^{11}$ Although no significant differences in FOXP3+ cell counts or FOXP3+/CD4+ cell ratios were observed between these 2 clusters, Cluster 1 patients showed a significantly higher risk for recurrence than Cluster 2 patients. Moreover, among Cluster 1 patients, the high FOXP3+/ CD4+ cell ratio group was associated with a significantly poorer relapse-free survival rate than that of the low
FOXP3+/CD4+ cell ratio group. Although there was no direct association between Tregs and prognosis according to each subtype, clustering based on tumor $I L 12 \mathrm{~A}$ and TGFB1 mRNA expression may be useful to exclude cases in which Tregs are not associated with disease prognosis.

The findings indicate that this method may be useful for excluding groups without immune escape by Tregs, thereby increasing the accuracy of analysis. Secondly, using Treg evaluation as a marker for treatment adaptation and effective prediction will likely enhance case exclusion accuracy and enable administration of treatments targeting Tregs (such as CTLA-4 inhibitors) in clinical practice.

FOXP3 staining of tumor cells has been reported 
Table 2. Comparison of clinical and experimental characteristics among relapsed and non-relapsed and Cluster 1 and 2 patients ( $\mathrm{n}=79$ ) with lung adenocarcinoma

\begin{tabular}{|c|c|c|c|c|c|c|}
\hline \multirow{2}{*}{ Characteristics } & \multicolumn{6}{|c|}{ All patients } \\
\hline & non-relapsed & relapsed & p-value & Cluster 1 & Cluster 2 & $p$-value \\
\hline Number of patients & 64 & 15 & & 44 & 35 & \\
\hline Age [years] (range) & $67(32-78)$ & $74(36-88)$ & 0.024 & $73(32-88)$ & $65(48-83)$ & 0.039 \\
\hline $\begin{array}{l}\text { Gender (\%) } \\
\text { male } \\
\text { female }\end{array}$ & $\begin{array}{l}21(32.8) \\
43(67.2)\end{array}$ & $\begin{array}{l}9(60.0) \\
6(40.0)\end{array}$ & 0.075 & $\begin{array}{l}20(45.5) \\
24(54.5)\end{array}$ & $\begin{array}{l}10(28.6) \\
25(71.4)\end{array}$ & 0.163 \\
\hline $\begin{array}{l}\text { Emphysema (\%) } \\
\text { yes } \\
\text { no } \\
\text { total size }[\mathrm{cm}] \text { (range) } \\
\text { invasion size }[\mathrm{cm}] \text { (range) }\end{array}$ & $\begin{array}{c}8(12.5) \\
56(87.5) \\
2.0(0.6-5.5) \\
1.2(0-5.4)\end{array}$ & $\begin{array}{c}5(33.3) \\
10(66.7) \\
3.8(1.2-8.0) \\
3.0(0.8-8.0)\end{array}$ & $\begin{array}{l}0.114 \\
<0.001 \\
<0.001\end{array}$ & $\begin{array}{c}12(27.3) \\
32(72.7) \\
2.5(1.2-8.0) \\
2.4(0.1-8.0)\end{array}$ & $\begin{array}{c}1(2.9) \\
34(97.1) \\
1.8(0.6-3.8) \\
0.6(0.0-3.8)\end{array}$ & $\begin{array}{l}0.005 \\
<0.001 \\
<0.001\end{array}$ \\
\hline $\begin{array}{l}\text { Tumor factor (\%) } \\
\text { Tis,1 } \\
\text { T2 4 }\end{array}$ & $\begin{array}{l}52(81.2) \\
12(18.8)\end{array}$ & $\begin{array}{c}5(33.3) \\
10(66.7)\end{array}$ & 0.001 & $\begin{array}{l}25(56.8) \\
19(43.2)\end{array}$ & $\begin{array}{c}32(91.4) \\
3(8.6)\end{array}$ & 0.001 \\
\hline $\begin{array}{l}\text { Nodal factor (\%) } \\
\text { N0 } \\
\text { N1,2 }\end{array}$ & $\begin{array}{c}63(98.4) \\
1(1.6)\end{array}$ & $\begin{array}{l}7(46.7) \\
8(53.3)\end{array}$ & $<0.001$ & $\begin{array}{c}36(81.8) \\
8(18.2)\end{array}$ & $\begin{array}{c}34(97.1) \\
1(2.9)\end{array}$ & 0.039 \\
\hline $\begin{array}{l}\text { Pathological stage (\%) } \\
\text { stage } 0, \text { I } \\
\text { stage II, III }\end{array}$ & $\begin{array}{c}60(93.8) \\
4(6.2)\end{array}$ & $\begin{array}{c}4(26.7) \\
11(73.3)\end{array}$ & $<0.001$ & $\begin{array}{l}30(68.2) \\
14(31.8)\end{array}$ & $\begin{array}{c}34(97.1) \\
1(2.9)\end{array}$ & 0.001 \\
\hline $\begin{array}{l}\text { pl factor (\%) } \\
\text { pl0 } \\
\text { pl1-3 }\end{array}$ & $\begin{array}{c}60(93.8) \\
4(6.2)\end{array}$ & $\begin{array}{l}9(60.0) \\
6(40.0)\end{array}$ & 0.002 & $\begin{array}{c}35(79.5) \\
9(20.5)\end{array}$ & $\begin{array}{c}34(97.1) \\
1(2.9)\end{array}$ & 0.037 \\
\hline $\begin{array}{l}\text { Lymphatic invasion (\%) } \\
\text { negative } \\
\text { positive }\end{array}$ & $\begin{array}{c}56(87.5) \\
8(12.5)\end{array}$ & $\begin{array}{c}5(33.3) \\
10(66.7)\end{array}$ & $<0.001$ & $\begin{array}{l}27(61.4) \\
17(38.6)\end{array}$ & $\begin{array}{c}34(97.1) \\
1(2.9)\end{array}$ & $<0.001$ \\
\hline $\begin{array}{l}\text { Vessel invasion (\%) } \\
\text { negative } \\
\text { positive }\end{array}$ & $\begin{array}{c}56(87.5) \\
8(12.5)\end{array}$ & $\begin{array}{l}6(40.0) \\
9(60.0)\end{array}$ & $<0.001$ & $\begin{array}{l}30(68.2) \\
14(31.8)\end{array}$ & $\begin{array}{c}32(91.4) \\
3(8.6)\end{array}$ & 0.014 \\
\hline $\begin{array}{l}\text { Grade (\%) } \\
\text { G1 } \\
\text { G2,3 }\end{array}$ & $\begin{array}{l}36(56.2) \\
28(43.8)\end{array}$ & $\begin{array}{c}1(6.7) \\
14(93.3)\end{array}$ & $<0.001$ & $\begin{array}{l}11(25.0) \\
33(75.0)\end{array}$ & $\begin{array}{c}26(74.3) \\
9(25.7)\end{array}$ & $<0.001$ \\
\hline $\begin{array}{l}\text { Histological subtype (\%) } \\
\text { lepidic } \\
\text { mucinous } \\
\text { acinar } \\
\text { papillary } \\
\text { solid }\end{array}$ & $\begin{aligned} & 29 \\
6 & (45.3) \\
15 & (23.4) \\
10 & (15.6) \\
4 & (6.2)\end{aligned}$ & $\begin{array}{l}1(6.7) \\
1(6.7) \\
2(13.3) \\
6(40.0) \\
5(33.3)\end{array}$ & 0.001 & $\begin{aligned} 8 & (18.2) \\
3 & (6.8) \\
12 & (27.3) \\
14 & (31.8) \\
7 & (15.9)\end{aligned}$ & $\begin{array}{l}22(62.9) \\
4(11.4) \\
5(14.3) \\
2(5.7) \\
2(5.7)\end{array}$ & $<0.001$ \\
\hline $\begin{array}{l}\text { Tumor FOXP3 staining (\%) } \\
\text { negative } \\
\text { positive }\end{array}$ & $\begin{array}{l}25(39.1) \\
39(60.9)\end{array}$ & $\begin{array}{l}11(73.3) \\
4(26.7)\end{array}$ & 0.022 & $\begin{array}{l}22(50.0) \\
22(50.0)\end{array}$ & $\begin{array}{l}14(40.0) \\
21(60.0)\end{array}$ & 0.496 \\
\hline $\begin{array}{l}\text { Cell count } \\
\text { CD4+ (range) } \\
\text { CD8+ (range) } \\
\text { FOXP3+ (range) }\end{array}$ & $\begin{array}{c}236(64-636) \\
142(66-418) \\
37(8-193)\end{array}$ & $\begin{array}{c}256(127-556) \\
194(67-284) \\
63(9-111)\end{array}$ & $\begin{array}{l}0.626 \\
0.127 \\
0.018\end{array}$ & $\begin{array}{c}246(106-636) \\
169(67-418) \\
44(9-163)\end{array}$ & $\begin{array}{c}236(64-556) \\
129(66-276) \\
40(8-193)\end{array}$ & $\begin{array}{l}0.782 \\
0.009 \\
0.594\end{array}$ \\
\hline $\begin{array}{l}\text { Cell count ratio } \\
\text { CD4+/CD8+ (range) } \\
\text { FOXP3+/CD4+ (range) } \\
\text { FOXP3+/CD8+ (range) }\end{array}$ & $\begin{array}{l}1.57(0.35-7.60) \\
0.16(0.05-0.48) \\
0.23(0.07-1.94)\end{array}$ & $\begin{array}{l}1.50(0.57-5.35) \\
0.23(0.07-0.44) \\
0.40(0.04-1.57)\end{array}$ & $\begin{array}{l}0.565 \\
0.012 \\
0.127\end{array}$ & $\begin{array}{l}1.49(0.47-7.60) \\
0.17(0.05-0.44) \\
0.23(0.04-1.94)\end{array}$ & $\begin{array}{c}1.92(0.35-4.18) \\
0.19(0.05-0.48) \\
0.3(0.08-1.20)\end{array}$ & $\begin{array}{l}0.129 \\
0.921 \\
0.319\end{array}$ \\
\hline $\begin{array}{l}\text { mRNA expression levels } \\
\text { IL12A (range) } \\
\text { TGFB1 (range) } \\
\text { FOXP3 (range) }\end{array}$ & $\begin{array}{l}1.18(0.07-5.58) \\
1.16(0.14-3.36) \\
1.12(0.10-5.12)\end{array}$ & $\begin{array}{l}0.62(0.09-1.39) \\
0.58(0.14-1.37) \\
0.54(0.11-2.24)\end{array}$ & $\begin{array}{c}0.006 \\
0.001 \\
<0.001\end{array}$ & $\begin{array}{l}0.64(0.07-1.67) \\
0.65(0.14-1.96) \\
0.74(0.11-2.98)\end{array}$ & $\begin{array}{l}1.57(0.86-5.58) \\
1.52(0.92-3.36) \\
1.29(0.10-5.12)\end{array}$ & $\begin{array}{l}<0.001 \\
<0.001 \\
<0.001\end{array}$ \\
\hline $\begin{array}{c}\text { Cluster (\%) } \\
\text { Cluster } 1 \\
\text { Cluster } 2\end{array}$ & $\begin{array}{l}30(46.9) \\
34(53.1)\end{array}$ & $\begin{array}{c}14(93.3) \\
1(6.7)\end{array}$ & 0.001 & & & \\
\hline
\end{tabular}

(+) - positive; CD - cluster of differentiation; FOXP3 - Forkhead box P3; IL12A - interleukin-12 subunit alpha; mRNA - messenger RNA; pl - pleural invasion; TGFB1 - transforming growth factor beta $1 ; G$ - grade. 
Table 3. Characteristics of tumor samples by tumor cell content (high $>46 \%$, intermediate $27-46 \%$, low $<27 \%$ )

\begin{tabular}{|c|c|c|c|c|}
\hline Parameter & \multicolumn{3}{|c|}{ All patients } & \multirow[b]{2}{*}{$p$-value } \\
\hline Tumor cell content & $\begin{array}{l}\text { high } \\
(n=27)\end{array}$ & $\begin{array}{l}\text { intermediate } \\
\quad(n=26)\end{array}$ & $\begin{array}{c}\text { low } \\
(n=26)\end{array}$ & \\
\hline $\begin{array}{l}\text { Patients per cluster (\%) } \\
\text { Cluster } 1 \\
\text { Cluster } 2\end{array}$ & $\begin{array}{l}16(59.3) \\
11(40.7)\end{array}$ & $\begin{array}{l}16(16.5) \\
10(38.5)\end{array}$ & $\begin{array}{l}12(46.2) \\
14(53.8)\end{array}$ & 0.482 \\
\hline $\begin{array}{l}\text { Cell count } \\
\text { CD4+ (range) } \\
\text { CD8+ (range) } \\
\text { FOXP3+ (range) }\end{array}$ & $\begin{array}{c}237(91-481) \\
156(67-418) \\
40(8-193)\end{array}$ & $\begin{array}{c}247(64-597) \\
152(66-331) \\
43(9-104)\end{array}$ & $\begin{array}{c}242(106-636) \\
136(83-336) \\
42(14-163)\end{array}$ & $\begin{array}{c}0.942 \\
0.566 \\
0.79\end{array}$ \\
\hline $\begin{array}{l}\text { mRNA expression levels } \\
\text { FOXP3 (range) } \\
\text { IL12A (range) } \\
\text { TGFB1 (range) }\end{array}$ & $\begin{array}{l}1.00(0.11-5.12) \\
0.92(0.07-4.91) \\
0.96(0.14-2.36)\end{array}$ & $\begin{array}{l}0.88(0.10-4.48) \\
0.97(0.18-5.58) \\
1.00(0.16-2.32)\end{array}$ & $\begin{array}{l}1.22(0.45-4.50) \\
1.19(0.25-4.74) \\
1.25(0.31-3.36)\end{array}$ & $\begin{array}{l}0.183 \\
0.272 \\
0.438\end{array}$ \\
\hline Extracted mRNA $[\mu \mathrm{l} / \mathrm{mL}]$ & $66.9(13.5-284)$ & $43.4(8.7-174.0)$ & $36.8(11.6-94.7)$ & 0.006 \\
\hline
\end{tabular}

(+) - positive; CD - cluster of differentiation; FOXP3 - Forkhead box P3; IL12A - interleukin-12 subunit alpha; TGFB1 - transforming growth factor beta 1.

Table 4. Univariate analysis of clinical and experimental characteristics influencing the relapse-free survival of all patients ( $\mathrm{n}=79$ ) and Cluster 1 patients $(\mathrm{n}=44)$ with lung adenocarcinoma

\begin{tabular}{|c|c|c|c|c|c|c|}
\hline \multicolumn{4}{|c|}{ All patients } & \multicolumn{3}{|c|}{ Cluster 1 patients } \\
\hline Characteristics & hazard ratio & $95 \% \mathrm{Cl}$ & $p$-value & hazard ratio & $95 \% \mathrm{Cl}$ & $p$-value \\
\hline Age; elder & 5.677 & $1.805-17.86$ & 0.003 & 1.913 & $0.600-6.102$ & 0.273 \\
\hline Gender; male & 2.578 & $0.917-7.248$ & 0.073 & 2.347 & $0.785-7.018$ & 0.127 \\
\hline Emphysema;Yes & 2.707 & $0.924-7.931$ & 0.07 & 1.49 & $0.499-4.454$ & 0.475 \\
\hline Total tumor size; large & 13.49 & $4.559-39.95$ & $<0.001$ & 3.861 & $1.133-9.466$ & 0.012 \\
\hline Invasion size; large & 8.532 & $2.711-26.85$ & $<0.001$ & 5.418 & $1.867-15.72$ & 0.002 \\
\hline Tumor factor; $2-4$ & 6.665 & $2.272-19.55$ & $<0.001$ & 2.899 & $0.970-8.662$ & 0.057 \\
\hline Nodal factor; $1-2$ & 21.97 & $7.599-63.51$ & $<0.001$ & 17.89 & $3.447-30.26$ & $<0.001$ \\
\hline p-stage; II-III & 20.29 & $6.363-64.67$ & $<0.001$ & 8.728 & $2.309-23.90$ & $<0.001$ \\
\hline Pleural invasion (+) & 6.542 & $2.316-18.48$ & $<0.001$ & 2.716 & $0.908-8.123$ & 0.074 \\
\hline Lymphatic invasion (+) & 8.932 & $3.037-26.27$ & $<0.001$ & 4.608 & $1.438-14.76$ & 0.01 \\
\hline Vessel invasion (+) & 7.182 & $2.546-20.26$ & $<0.001$ & 3.591 & $1.242-10.38$ & 0.018 \\
\hline $\mathrm{G} ; 2-3$ & 14.9 & $1.959-113.4$ & 0.009 & 5.373 & $0.702-41.12$ & 0.105 \\
\hline Subtype; solid & 5.279 & $1.796-15.52$ & 0.002 & 2.684 & $0.839-8.583$ & 0.096 \\
\hline CD4+ cell; high & 1.173 & $0.425-3.234$ & 0.758 & 1.054 & $0.369-3.006$ & 0.922 \\
\hline CD8+ cell; high & 2.009 & $0.687-5.878$ & 0.203 & 1.322 & $0.458-3.811$ & 0.606 \\
\hline FOXP3+ cell; high & 3.11 & $0.989-9.775$ & 0.052 & 2.947 & $0.922-9.421$ & 0.068 \\
\hline CD4+/CD8+; low & 1.173 & $0.417-3.175$ & 0.758 & 1.039 & $0.364-2.963$ & 0.943 \\
\hline FOXP3+/CD4+; high & 4.188 & $1.332-13.17$ & 0.014 & 7.691 & $2.129-27.78$ & 0.002 \\
\hline FOXP3+/CD8+; high & 3.099 & $0.986-9.742$ & 0.053 & 4.745 & $1.625-13.86$ & 0.004 \\
\hline Tumor FOXP3; (+) & 0.2593 & $0.083-0.815$ & 0.021 & 0.315 & $0.099-1.007$ & 0.051 \\
\hline FOXP3 expression; low & 4.329 & $1.567-11.96$ & 0.005 & 3.213 & $1.072-9.626$ & 0.037 \\
\hline IL12A expression; low & 10.81 & $2.438-47.96$ & 0.002 & 1.411 & $0.489-4.067$ & 0.524 \\
\hline TGFB1 expression; low & 9.257 & $2.607-32.87$ & $<0.001$ & 3.276 & $1.025-10.47$ & 0.045 \\
\hline Tumor cell content ratio; low & 0.2037 & $0.072-0.575$ & 0.003 & 0.280 & $0.067-1.175$ & 0.08 \\
\hline
\end{tabular}

(+) - positive; CD - cluster of differentiation; FOXP3 - Forkhead box P3; G - grade; IL12A - interleukin-12 subunit alpha; $\mathrm{P}$ - pathological; TGFB1 - transforming growth factor beta 1; 95\% Cl - 95\% confidence interval. 
Table 5. Multivariate analysis of risk factors for relapse-free survival rate among all patients $(n=79)$ and among Cluster 1 patients $(n=44)$ with lung adenocarcinoma

\begin{tabular}{|l|c|c|c|}
\multicolumn{1}{|c|}{ Characteristics } & $\begin{array}{c}\text { Hazard } \\
\text { ratio }\end{array}$ & \multicolumn{2}{|c|}{ 95\% Cl } \\
\hline \multicolumn{4}{|c|}{ All patients } \\
\hline nodal factor; 1-2 & 5.219 & $1.576-17.29$ & 0.007 \\
\hline p-stage; II-III & 11.37 & $3.101-41.71$ & $<0.001$ \\
\hline vessel invasion (+) & 4.817 & $1.603-14.48$ & 0.005 \\
\hline & Cluster 1 patients \\
\hline total tumor size; large & 3.88 & $1.223-12.31$ & 0.021 \\
\hline nodal factor; 1-2 & 7.683 & $2.317-22.17$ & $<0.001$ \\
\hline vessel invasion (+) & 3.945 & $1.005-8.889$ & 0.022 \\
\hline FOXP3+/CD4+; high & 4.461 & $1.530-21.80$ & 0.031 \\
\hline
\end{tabular}

(+) - positive; CD - cluster of differentiation; FOXP3 - Forkhead box P3; $\mathrm{p}$ - pathological; $95 \% \mathrm{Cl}$ - 95\% confidence interval.

in various types of malignancies, including breast, gastric and lung cancer. ${ }^{3,7,12-14,22,23}$ In gastric cancer, tumor FOXP3+ staining has been reported as a favorable prognostic factor. ${ }^{24}$ However, tumor FOXP3+ expression was reported as a poor prognostic factor for oral and orohypopharyngeal squamous cell carcinomas. ${ }^{25}$ In breast cancer, the effect of tumor FOXP3+ staining reportedly differs according to location, with nuclear expression associated with a favorable prognosis and cytoplasmic expression associated with a poor prognosis. ${ }^{23}$ One study suggested that, in lung cancer, tumor FOXP3+ staining was not a prognostic factor, ${ }^{3}$ while another study reported that high tumor FOXP3 expression was associated with a favorable prognosis. ${ }^{7}$ The current study did not observe a correlation between lung tumor FOXP3+ staining and FOXP3 expression. Additionally, both FOXP3+ staining as well as high FOXP3 expression in lung tumor samples were associated with a favorable prognosis.

Highly specific information can be elicited by examining the FOXP3+/CD4+ ratios and subpopulations from IL12A and TGFB1, as well as by considering non-Tregs and excluding groups that are unrelated to prognosis.

This study had some limitations. First, FOXP3 mRNA was derived from both tumor cells and other cells in the tumor microenvironment. Multivariate analysis did not reveal a significant difference in relapse-free survival. It cannot be conclusively stated that tumor FOXP3 expression is a poor prognostic factor. However, the effect of tumor FOXP3 expression on assessing tumor-infiltrating Tregs was not negligible, as indicated by mRNA expression of FOXP3 in tumor specimens. Thus, when assessing FOXP3+ T cells the use of tumor FOXP3 mRNA expression should be avoided in tumors that frequently express $F O X P 3$. Second, although there were no significant differences in mRNA expression of FOXP3, IL12A and TGF-B1 between the 3 groups when divided according to the tumor cell content, higher tumor cell content ratio was related to recurrence in univariate analysis, and the higher tumor cell content group tended to have lower mRNA expression of IL12A and TGFB1. Therefore, tumor cell content ratio can be a confounding factor of mRNA expression analysis when sampling tumor cells and interstitial tissue together.

This is the first study to apply cluster classification of $I L 12 A$ and TGFB1 to lung cancer. In addition, we demonstrated the possibility of selecting non-Tregs without the need for flow cytometry analysis.

\section{Conclusions}

This study suggests that assessing tumor-infiltrating Tregs in lung cancer from FFPE tissues may be useful in evaluating FOXP3+/CD4+ cell ratios and classifying tumors according to IL12A and TGFB1 mRNA expression levels. However, care should be taken, as tumor cells frequently express FOXP3. Further studies are needed to clarify this diagnostic confounder.

\section{ORCID iDs}

Hiroyasu Matsuoka (D) https://orcid.org/0000-0002-7850-5258 Hirochika Matsubara (i) https://orcid.org/0000-0001-7622-4957 Aya Sugimura (1) https://orcid.org/0000-0002-9241-6948 Tsuyoshi Uchida (D) https://orcid.org/0000-0002-5462-6565 Tamo Kunimitsu (D) https://orcid.org/0000-0001-7557-4891 Tomofumi Ichihara (D) https://orcid.org/0000-0002-5072-8425 Yuichiro Oonuki (D) https://orcid.org/0000-0002-4448-1403 Yoshihiro Miyauchi (D) https://orcid.org/0000-0003-2010-1434 Tetsuo Kondo (D) https://orcid.org/0000-0003-2268-0302 Hiroyuki Nakajima (D) https://orcid.org/0000-0003-1555-4033

\section{References}

1. Shang B, Liu Y, Jiang SJ, Liu Y. Prognostic value of tumor-infiltrating FoxP3+ regulatory T cells in cancers: A systematic review and metaanalysis. Sci Rep. 2015;5:15179.

2. Shimizu K, Nakata M, Hirami Y, Yukawa T, Maeda A, Tanemoto K. Tumor-infiltrating Foxp3+ regulatory $T$ cells are correlated with cyclooxygenase-2 expression and are associated with recurrence in resected non-small cell lung cancer. J Thorac Oncol. 2010;5(5): 585-590.

3. Tao H, Mimura Y, Aoe K, et al. Prognostic potential of FOXP3 expression in non-small cell lung cancer cells combined with tumor-infiltrating regulatory T cells. Lung Cancer. 2012;75(1):95-101.

4. Hasegawa T, Suzuki H, Yamaura T, et al. Prognostic value of peripheral and local forkhead box $\mathrm{P} 3+$ regulatory $\mathrm{T}$ cells in patients with non-small-cell lung cancer. Mol Clin Oncol. 2014;2(5):685-694.

5. O'Callaghan DS, Rexhepaj E, Gately K, et al. Tumour islet Foxp3+ T-cell infiltration predicts poor outcome in nonsmall cell lung cancer. Eur Respir J. 2015;46(6):1762-1772.

6. Jackute J, Zemaitis $M$, Pranys $D$, et al. The prognostic influence of tumor infiltrating Foxp3(+)CD4(+), CD4(+) and CD8(+) T cells in resected non-small cell lung cancer. J Inflamm (Lond). 2015;12:63.

7. Usó M, Jantus-Lewintre E, Bremnes RM, et al. Analysis of the immune microenvironment in resected non-small cell lung cancer: The prognostic value of different T lymphocyte markers. Oncotarget. 2016; 7(33):52849-52861.

8. Kinoshita T, Muramatsu R, Fujita T, et al. Prognostic value of tumorinfiltrating lymphocytes differs depending on histological type and smoking habit in completely resected non-small-cell lung cancer. Ann Oncol. 2016;27(11):2117-2123.

9. Miyara M, Yoshioka Y, Kitoh A, et al. Functional delineation and differentiation dynamics of human CD4+ T cells expressing the FoxP3 transcription factor. Immunity. 2009;30(6):899-911. 
10. Sugiyama D, Nishikawa H, Maeda Y, et al. Anti-CCR4 mAb selectively depletes effector-type FoxP3+CD4+ regulatory T cells, evoking antitumor immune responses in humans. Proc Natl Acad Sci U S A. 2013; 110(44):17945-17950.

11. Saito T, Nishikawa H, Wada H, et al. Two FOXP3(+)CD4(+) T cell subpopulations distinctly control the prognosis of colorectal cancers. Nat Med. 2016;22(6):679-684.

12. Karanikas V, Speletas M, Zamanakou M, et al. Foxp3 expression in human cancer cells. J Transl Med. 2008;6:19.

13. Dimitrakopoulos FI, Papadaki H, Antonacopoulou AG, et al. Association of FOXP3 expression with non-small cell lung cancer. Anticancer Res. 2011;31(5):1677-1683.

14. Li Y, Li D, Yang W, Fu H, Liu Y, Li Y. Overexpression of the transcription factor FOXP3 in lung adenocarcinoma sustains malignant character by promoting G1/S transition gene CCND1. Tumour Biol. 2016;37(6): 7395-7404.

15. Travis WD, Brambilla E, Noguchi M, et al. International Association for the Study of Lung Cancer/American Thoracic Society/European Respiratory Society International Multidisciplinary Classification of Lung Adenocarcinoma. J Thorac Oncol. 2011;6(2):244-285.

16. Borczuk AC. Prognostic considerations of the new World Health Organization classification of lung adenocarcinoma. Eur Respir Rev. 2016; 25(142):364-371.

17. Goldstraw P, Chansky K, Crowley J, et al; International Association for the Study of Lung Cancer Staging and Prognostic Factors Committee, Advisory Boards, and Participating Institutions; International Association for the Study of Lung Cancer Staging and Prognostic Factors
Committee Advisory Boards and Participating Institutions. The IASLC Lung Cancer Staging Project: Proposals for revision of the TNM stage groupings in the forthcoming (Eighth) Edition of the TNM Classification for Lung Cancer. J Thorac Oncol. 2016;11(1):39-51.

18. Sakaguchi S. Naturally arising Foxp3-expressing CD25+CD4+ regulatory $\mathrm{T}$ cells in immunological tolerance to self and non-self. Nat Immunol. 2005;6(4):345-352.

19. Zou W. Regulatory T cells, tumor immunity and immunotherapy. Nat Rev Immunol. 2006;6(4):295-307.

20. Nishikawa H, Sakaguchi S. Regulatory T cells in cancer immunotherapy. Curr Opin Immunol. 2014;27:1-7.

21. Li L, Qi L, Liang Z, et al. Transforming growth factor- $\beta 1$ induces EMT by the transactivation of epidermal growth factor signaling through HA/CD44 in lung and breast cancer cells. Int J Mol Med. 2015;36(1): 113-122.

22. Martin F, Ladoire S, Mignot G, Apetoh L, Ghiringhelli F. Human FOXP3 and cancer. Oncogene. 2010;29(29):4121-4129.

23. Takenaka M, Seki N, Toh $U$, et al. FOXP3 expression in tumor cells and tumor-infiltrating lymphocytes is associated with breast cancer prognosis. Mol Clin Oncol. 2013;1(4):625-632.

24. Ma GF, Miao Q, Liu YM, et al. High FoxP3 expression in tumour cells predicts better survival in gastric cancer and its role in tumour microenvironment. Br J Cancer. 2014;110(6):1552-1560.

25. Weller P, Bankfalvi A, Gu X, et al. The role of tumour FOXP3 as prognostic marker in different subtypes of head and neck cancer. Eur J Cancer. 2014;50(7):1291-1300. 